\title{
Theological Basis for Obedience to the Government During the Covid-19 Pandemic in Indonesia
}

\author{
Made Nopen Supriadi ${ }^{1 *}$, Manase Gulo², Iman Kristina Halawa ${ }^{3}$ \\ ${ }^{1,2,3}$ Sekolah Tinggi Teologi Arastamar Bengkulu, Indonesia \\ Email: ${ }^{1 *}$ madenopensupriadi@sttab.ac.id
}

\begin{abstract}
The Coronavirus Disease 2019 (Covid-19) pandemic continues to increase its spread. The government has made efforts to contain the space by enacting several health protocols by March 2020. However, many Indonesians have not followed through on this appeal, and this situation also occurs in the context of the church. The Covid-19 pandemic is predicted to subside at the end of August or early September 2020, but this has not been realized. The authors observe the phenomenon of failure to recognize this due to a lack of adherence to health protocols. Obedience is an important principle that needs to be understood and implemented by all Indonesian people, especially Christians and church leaders. This research used the descriptive method to identify the phenomenon to get to the main problem, namely the concept of obedience. This research got the theological formulation of obedience to the government, namely priestly service, political service, and submission to government policies that have justice and humanity values.
\end{abstract}

Key Words: FoundationTheological, Obedience, Government, Covid-19 Pandemic

\begin{abstract}
ABSTRAK:Pandemi Coronavirus Disease 2019 (Covid-19) terus meningkat penyebarannya. Pemerintah telah melakukan upaya untuk mengatasi penyebaran dengan memberlakukan beberapa protokol kesehatan pada bulan Maret 2020, namun masih banyak masyarakat Indonesia belum menaati imbauan tersebut, dan situasi tersebut juga terjadi dalam konteks gereja. Pandemi Covid-19 diprediksi akan reda pada akhir Agustus atau awal September 2020, namun hal tersebut tidak terealisasi. Penulis mengamati fenomena gagalnya realisasi tersebut karena kurangnya ketaatan terhadap penerapan protokol kesehatan. Ketaatan adalah prinsip penting yang perlu dimengerti dan diimplementasikan oleh seluruh masyarakat Indonesia, secara khusus bagi umat Kristen dan para pemimpin gereja. Penelitian ini memakai metode deskriptif melakukan identifikasi fenomena untuk mendapatkan pokok permasalahan yaitu konsep ketaatan. Hasil penelitian menunjukkan formulasi teologis ketaatan kepada pemerintah yaitu pelayanan keimaman, pelayanan politis dan ketundukan kepada kebijakan pemerintah yang memiliki nilai keadilan serta kemanusiaan.
\end{abstract}

Kata Kunci:Landasan Teologis, Ketaatan, Pemerintah, Pandemi Covid-19

Article History: Submitted: 13 Februari $2021 \quad$ Revised: 15 Mei $2021 \quad$ Published: July 28, 2021

\section{PENDAHULUAN}

Dunia saat ini masih menghadapi wabah coronavirus disease 2019 (Covid-19). Data saat ini sudah lebih 220 negara sedang merasakan dampak penyebaran Covid-19, salah satunya adalah Negara Indonesia. Data Badan kesehatan dunia/World Health Organization (WHO) pada tanggal 21 November 2020 merilis data terbaru kasus pandemic Covid-19, yaitu 357.538 kasus baru pada hari ini dengan total
56.982.476 kasus orang yang terkonfirmasi terkena Covid-19 dan 1.361.847 orang telah meninggal dunia (N, 2020b). Indonesia secara khusus merilis pada tanggal 21 November 2020 kasus penyebaran Covid19 mencapai 493.308 kasus, meninggal 15.774 orang dan sembuh 413.955 orang (N, 2020a). Dengan demikian kondisi di Indonesia sudah mulai mengalami penurunan angka kematian, meskipun tetap ada pe- 
nambahan kasus baru dan data tersebut menunjukkan Indonesia tetap waspada terhadap pandemi Covid-19.

WHO telah memberikan protokol kesehatan dalam menghadapi penyebaran Covid-19, yaitu: menjaga jarak sosial (social distancing), menjaga jarak kontak fisik (physical distancing), diam di rumah (stay at home), bekerja dari rumah (work from home), memakai masker, rajin membersihkan tangan dengan menggunakan handsanitizer atau mencuci tangan dengan sabun dan menjaga daya tahan tubuh serta ada penerapan lock down (Devlieghere \& Roose, 2020). Pemerintah Indonesia pada bulan Maret 2020 telah merespon untuk melakukan penerapan protokol kesehatan yang dicanangkan oleh WHO, namun Pemerintah Indonesia menyesuaikan dengan keadaan masyarakat Indonesia sehingga tidak melakukan lock down tetapi Pembatasan Sosial Berskala Besar (PSBB), transisi dan ketat (Thorik, 2020). Satuan Tugas (Satgas) penanganan Covid-19 memberitakan bahwa protokol kesehatan yang diterapkan pemerintah, secara khusus PSBB menimbulkan dampak sosial, salah satunya dampak ekonomi. Laporan Satgas Covid-19 memberitakan bahwa Pemerintah telah melaksanakan kebijakan untuk mengatasi masalah ekonomi masyarakat Indonesia dalam suasana PSBB, diantaranya dengan memberikan bantuan uang tunai atau sembako (2020b). Dengan demikian Pemerintah telah melakukan kebijakan yang baik kepada masyarakat Indonesia yang terdampak Covid19 dan penerapan PSBB.

Fenomena penyebaran Covid-19 lebih banyak disebabkan karena ketidaktaatan terhadap protokol kesehatan. Sebuah perhitungan ilmiah menunjukkan bahwa Covid-19 akan berakhir pada bulan Agustus atau awal september jika seluruh masyarakat Indonesia taat pada protokol kesehatan yang disarankan oleh pemerintah (Putri, 2020). Perhitungan ahli Matematika tersebut tidak terealisasi, karena banyak warga Indonesia yang tidak menaati untuk menerapkan protokol kesehatan. Dengan demikian meskipun pemerintah telah memberikan imbauan tentang protokol kesehatan dan pengaturan yang ketat, tetapi hal tersebut tidak cukup. Satgas Covid-19 melaporkan ada daerah merah telah kembali menjadi hijau, analisis di lapangan menunjukkan faktor utama adalah dukungan masyarakat dalam mengimplementasikan ketaatan terhadap protokol kesehatan. Provinsi Bengkulu adalah salah satu Provinsi yang terdampak Covid-19, pada tanggal 09 Juli 2020 dilaporkan bahwa Kabupaten Bengkulu Selatan dan Kaur telah berganti statusnya dari zona merah menjadi zona hijau, karena 8 orang yang dinyatakan positif Covid-19 semua telah sembuh, menanggapi situasi tersebut kepala Dinas Kesehatan (Dinkes) Provinsi Bengkulu Herwan Antoni mengingatkan agar masyarakat Bengkulu Selatan tetap taat terhadap protokol kesehatan (2020c). Pada tanggal 02 Januari 2021 Satuan Gugus Tugas (Satgas) Covid-19 Kabupaten Bengkulu Selatan mencatat ada 85 kasus terkonfirmasi, dengan 18 positif, 59 sembuh dan 8 meninggal, situasi tersebut menjadikan daerah Kabupaten Bengkulu Selatan dari Zona Hijau kembali lagi menjadi Zona Merah (Bengkulu, 2021). Dengan demikian ketaatan terhadap protokol kesehatan memiliki peranan penting selama menanti ilmuwan medis menemukan vaksin terhadap Covid19 dan mengurangi penyebaran Covid-19.

Pandemi Covid-19 juga memengaruhi kehidupan umat Kristen di Indonesia salah satunya dalam pelaksanaan ibadah di gereja secara tatap muka dan pelayanan pastoral konseling (Silitonga, 2020). Menghadapi situasi Covid-19 ada beragam respon dari gereja terhadap protokol kesehatan yang dicanangkan oleh Pemerintah (Sugianto, 2020). Berbagai usulan untuk melaksanakan kegiatan ibadah tanpa tatap muka mulai dilakukan, baik itu dengan cara online (Berutu \& Siahaan, 2020) dan ibadah rumah (Hutahaean, Silalahi, \& Simanjuntak, 2020), (Marbun, 2020). Namun pemikiran tersebut belum dilaksanakan oleh banyak gereja di Indonesia, diantaranya beberapa gereja yang ada di provinsi Bengkulu yang tetap melaksanakan ibadah tatap muka meskipun telah ada himbauan PSBB di Kota Bengkulu pada Bulan Maret sampai Juni (2020a). Alasan gereja tidak segera merespon imbauan pemerintah pada bulan 
Maret 2020 dikarenakan mengalami masalah biaya operasional, sebab ada jemaat yang tidak memberikan persembahan jika tidak ada ibadah secara tatap muka (B \& P, 2021). Kemudian ada gereja yang tetap melaksanakan ibadah secara tatap muka karena memiliki pandangan teologis yang terlalu menekankan iman sehingga mengabaikan himbauan pemerintah (Supriadi \& Halawa, 2020). Dengan demikian di Indonesia masih ada gereja di dalam lingkup zona merah tetap melakukan ibadah tatap muka dan hal tersebut melanggar ketetapan dari pemerintah.

Merespon situasi tersebut Direktorat Jenderal Bimbingan Masyarakat Kristen (Dirjen Bimas Kristen) Republik Indonesia pada bulan April segera memberikan imbauan kepada delapan pemimpin Aras Gereja di Indonesia untuk menyadari bahaya COVID-19 dan ikut turut serta melaksanakan protokol kesehatan (Pentury, 2020). Gereja-gereja mulai merespon imbauan pemerintah untuk melaksanakan ibadah secara daring (Dwiraharjo, 2020). Data-data tersebut menunjukkan bahwa masih ada gereja yang kurang taat dan responsif terhadap aturan atau kebijakan pemerintah.Sebagai upaya berkelanjutan dan antisipasi dimasa yang akan datang maka perlu dilakukan penelitian tentang 'Landasan Teologis Ketaatan Kepada Pemerintah Pada Masa Pandemi COVID-2019 di Indonesia'.

\section{METODE}

Penelitian ini menggunakan metode penelitian deskriptif (descriptive research). Penggunaan metode deskriptif pada penelitian ini karena penulis melakukan kajian untuk membuka informasi terhadap fenomena yang diamati (Zaluchu, 2020b). Pembahasan artikel menjadi dua bagian. Pertama, pembahasan landasan teologis ketaatan terhadap pemerintah yang berdasarkan Alkitab, yang dimulai dari konteks Perjanjian Lama dan Perjanjian Baru dengan langkah-langkah memberikan penjelasan secara deskripsi terhadap kisah Alkitab yang menunjukkan konteks adanya ketaatan terhadap pemerintah, setelah itu penulis juga akan memberikan kesimpulan analisis kisah Alkitab tersebut disertai dengan pandangan para pakar yang telah melakukan kajian terhadap topik yang disajikan. Kedua, analisis kebijakan pemerintah secara prinsip untuk melihat kualitas kebijakan, pada variabel ini penulis akan memberikan jawaban apakah kebijakan pemerintah tentang protokol kesehatan memiliki nilai yang mendasar untuk ditaati oleh umat Kristen di Indonesia (Ridha, 2017). Kedua variabel tersebut akan dipadukan untuk menjawab latar belakang penelitian. Pada bagian akhir penulis akan memberikan kesimpulan dan saran. Strategi penyelesaian penelitian ini juga melibatkan wawancara dan kajian literatur baik dari artikel jurnal yang berkaitan dan buku-buku referensi yang dibutuhkan.

\section{HASIL DAN PEMBAHASAN}

John M. Frame memberikan definisi teologi adalah aplikasi Alkitab oleh pribadi untuk setiap area kehidupannya (Nego, 2020). Teologi tidak hanya menjadikan Allah sebagai objek pembelajaran, tetapi juga sebagai subjek dalam belajar teologi. Teologi merupakan prinsip yang memengaruhi seluruh kehidupan manusia. Kualitas teologi ditunjukkan melalui praktik kehidupan praktis (Mawikere, 2019). Dengan demikian kehidupan orang percaya ditentukan dari pemahaman teologisnya, salah satunya adalah adalah tindakan dalam ketaatan, ditentukan oleh pemahaman teologisnya, jika pemahaman teologi ketaatan bermasalah maka praktik hidup ketaatannya juga bermasalah dan jika pemahaman teologi tentang ketaatannya benar maka praktik hidupnya menjadi benar.

\section{Landasan Teologis Ketaatan Kepada Pemerintah Dalam Perjanjian Lama}

Perjanjian Lama menuliskan ada beberapa kisah yang menunjukkan sikap-sikap atau respons terhadap seorang raja atau penguasa. Wright (2016) menuliskan adanya pelayanan keimaman dan pelayanan politis umat Israel terhadap para penguasa atau raja-raja baik dalam konteks nasional Israel dan Internasional. Wright (2016) menuliskan Israel disebut 'kerajaan imam'. Keluaran 19:6 merupakan pernya- 
taan Allah langsung tentang keturunan Yakub (umat Israel) kepada Musa saat di gunung Sinai. Israel ada demi bangsa-bangsa lain sebagai perantara antara Allah dan bangsa lain (Supriadi, Halawa, \& Daeli, 2020, p. 20). Secara prinsip tindakan keimaman tersebut sudah terlihat dalam kehidupan nenek moyang umat Israel yaitu ketika Abraham berdoa bagi Sodom dan Gomora (Kej. 19). Dengan demikian dalam konteks Keluaran 19:6 merupakan sebuah afirmasi paradigma umat Allah, meskipun Allah telah menghukum bangsa Mesir di hadapan umat Israel, namun Allah tetap mengingatkan bahwa umat Israel tetap memiliki tanggung jawab keimaman, hal tersebut dapat dilihat dalam tindakan Allah yang menetapkan Musa dan Harun sebagai perantara ketika tulah terjadi di Mesir, Allah mendengarkan permohonan Musa dan Harun sehingga ada tulah-tulah yang berhenti ketika Musa menjalankan fungsinya dalam keimaman, yaitu tulah katak (Kel. 8: 12-13), tulah lalat pikat (Kel. 8: 30-31), tulah hujan es (Kel. 9: 27-33) dan tulah belalang (Kel. 10: 18-19) (Zaluchu, 2020a). Tindakan Musa dan Harun menunjukkan ketaatan dalam konteks keimaman kepada penguasa Mesir, meskipun tulah tersebut diberikan Tuhan, namun Tuhan juga menetapkan Musa dan Harun memiliki peran keimaman yaitu dapat berdoa dan memohon kepada Allah bagi penguasa Mesir yang tidak memiliki iman yang sama dengan umat Israel. Prinsip keimaman umat Israel kepada bangsa-bangsa disekitarnya dapat dilihat juga pada konteks para nabi. Yunus yang pergi menyampaikan berita pertobatan bagi Niniwe (Yun. 3), sebelum kerajaan Asyur melakukan invansi militer ke Israel Utara pada tahun 722 SM, Allah telah menetapkan Yunus untuk menjalankan fungsi keimaman dan kenabian kepada penduduk di ibu kota Asyur yaitu Niniwe pada tahun 780 SM (Balchin et al., 2000). Pada konteks pembuangan umat Israel di Kerajaan Babel yaitu tahun 605, 597 dan 586 SM, nabi Yeremia menuliskan surat kepada umat Israel dipembuangan agar berdoa untuk kota tempat mereka dibuang (Yer. 29: 7) (Wright, 2016). Dengan demikian sikap umat Allah terhadap pemerintahan kera- jaan lain adalah memberikan pelayanan keimaman, sekalipun umat Israel mengalami tindakan pembuangan, mengenai pembebasan adalah kedaulatan Allah.

Umat Allah dalam Perjanjian Lama selain berperan sebagai pelayan keimaman, juga memberikan pelayanan politis (Susanta, 2019). Pelayanan politis ditunjukkan baik kepada kerajaan lain maupun kepada umat kerajaan Israel sendiri, mengenai hal tersebut Wright (2016) menuliskan bahwa Yusuf dan Daniel adalah contoh perwujudan sikap pelayanan secara politis di luar dari wilayah nasionalis Israel. Dalam konteks Kejadian 41:40-45 Firaun melantik Yusuf menjadi penguasa atas seluruh tanah Mesir, setelah Yusuf memberikan masukan dan strategi dalam menghadapi bencana kelaparan yang akan datang (Kej. 41:33-39). Yusuf meskipun memiliki latar belakang kebangsaan yang berbeda dengan kerajaan Mesir. Ia tetap tunduk pada ketetapan Firaun dan memberikan kontribusi ide-ide yang sangat baik bagi Kerajaan Mesir dalam hal strategi ekonomi dan politik (Novalina, 2020). Boiliu (2018) memberikan fokus dasar teologis perwujudan ketaatan umat Israel terhadap penguasa dalam Perjanjian Lama melalui kisah Daniel dan sahabat-sahabatnya, yang pada konteks saat berada dalam pembuangan di Babel pada tahun 605 SM. Daniel dan para sahabatnya memiliki sifat yang loyal dalam memberikan kontribusi ide-ide yang membangun kerajaan Babel (Dan. 2:46-49). Meskipun demikian Daniel dan para sahabatnya juga menunjukkan penolakan untuk tunduk terhadap aturan raja Nebukadnezar yang bertentangan dengan prinsip nasional iman umat Israel yang didasarkan pada Shema Yisrael (Boiliu, 2018). Dalam Daniel 3:16-18 para Sahabat Daniel, yaitu: Sadrakh, Mesakh dan Abednego menolak untuk memuja dewa Babel, bahkan Daniel juga menolak untuk tidak melaksanakan doa kepada Allah Israel sekalipun sudah ada larangan (Dan. 6:11-12). Dengan demikian baik Yusuf, Daniel dan para sahabatnya menunjukkan sikap patuh dan tunduk kepada penguasa dalam konteks tanggung jawab umum, bahkan mereka bekerja dengan sangat 
profesional dalam bidang umum, baik itu administrasi, strategi ekonomi, politik dan pendidikan. Namun ketundukkan tersebut memiliki batasan yaitu tetap menjaga identitas spiritualitas, sehingga meskipun berbeda iman, namun memikirkan kemajuan suatu bangsa dimana berada adalah tanggung jawab bersama.

Pada konteks Kerajaan Israel banyak peristiwa menunjukkan respon rakyat Israel terhadap sikap dan peraturan para raja yang memerintah. Wright (2016) menuliskan Elia dan Obaja memberikan respons perlawanan terhadap raja Ahab yang tidak menyembah YHWH. Elia dan Obaja berada dalam konteks yang berbeda, Elia menentang raja Ahab namun berada di luar struktur pemerintahan raja Ahab, sedangkan Obaja menentang raja Ahab namun berada dalam struktur pemerintahan raja Ahab (1Raj. 18: 3). Wright menuliskan bahwa posisi Obaja dalam menentang raja Ahab justru lebih sulit karena berada di dalam 'kandang singa' politik dan harus menyelamatkan seratus nabi Tuhan yang terancam nyawanya (Wright, 2016). Boiliu secara filosofis teologis menjelaskan sikap tunduk umat Israel kepada YHWH memengaruhi etika politik dalam Kerajaan Israel, raja Israel harus tunduk tanpa syarat kepada YHWH dan rakyat bisa memilih tidak tunduk kepada raja jika raja tidak tunduk pada YHWH. Sebaliknya, jika raja tunduk pada YHWH maka rakyat secara mutlak tunduk kepada raja (Boiliu, 2018). Respon secara politis umat Israel terhadap penguasa dari kerajaan lain terlihat dalam kisah Ester, sikap yang bijaksana diperlukan dalam merespon dan mencari solusi untuk mengubah keputusan seorang raja. Ester dan Mordekhai mengajak umat Israel untuk tidak menunjukkan sikap memberontak dan memberi perintah untuk berdoa agar hikmat Tuhan menolong Ester untuk berbicara kepada raja Ahasyweros (Est. 4: 15-16 dan 7: 1-7).

Dengan demikian dalam Perjanjian Lama menjelaskan adanya batasan ketundukkan terhadap peraturan raja menyangkut dengan prinsip rohani. Namun Perjanjian Lama juga memberikan sikap ketundukkan secara totalitas kepada penguasa dalam berbagai segi pemerintahan baik dalam penegakan hukum, keadilan dan yang berkaitan dengan administrasi. Ketaatan terhadap penguasa merupakan ekspresi dari ketundukan penguasa kepada Allah dan ketidaktaatan terhadap penguasa karena sikap penguasa yang tidak tunduk pada Allah serta dosa yang dilakukan oleh penguasa (Arifianto \& Santo, 2020). Perjanjian Lama memberikan konsep agar umat Israel memberikan kontribusi yang baik dan bertindak profesional terhadap hal-hal umum yang berguna bagi kemajuan suatu bangsa tanpa menghilangkan identitas spiritual serta tanggung jawab spiritual sebagai imam bagi bangsa-bangsa lain.

\section{Landasan Teologis Ketaatan Kepada Pemerintah Dalam Perjanjian Baru}

Landasan teologis dalam Perjanjian Baru tentang sikap ketundukkan terhadap pemerintah, dapat dilihat dalam beberapa teks yaitu Matius 22: 15-22. Kent (2008) memberikan penjelasan mengenai konteks Matius 22:15-22 tentang pertanyaan yang diberikan kepada Yesus dari orang-orang Farisi dengan motivasi untuk mendapatkan kesalahan Yesus. Orang Farisi memberikan pertanyaan mengenai pembayaran pajak kepada Kaisar, apakah perlu dilakukan atau tidak, karena pada konteks saat itu sikap tidak membayar pajak dapat dilaporkan sebagai pelanggaran dan pemberotakan terhadap penguasa Romawi. Konteks saat itu pajak menjadi sumber pemasukan yang berguna bagi operasional pemerintahan di kekaisaran Romawi, secara khusus dalam pembangunan dan militer untuk menciptakan kestabilan politik dan keamanan. Yesus menjawab pertanyaan orang-orang Farisi dengan memberikan pandangan politis dan spiritual tentang sikap terhadap kebijakan Kaisar yang menetapkan pajak. Yesus memberikan konsep bahwa apa yang wajib diberikan kepada Kaisar maka berikan kepada Kaisar dan apa yang wajib diberikan kepada Allahberikan kepada Allah. Dengan demikian Tuhan Yesus dalam konteks tersebut menunjukkan perlunya sikap tunduk secara benar kepada pemerintah namun tidak meniadakan tanggung jawab 
kepada Allah. Meskipun pada prinsipnya ketundukkan mutlak tetap diberikan hanya kepada Allah (Kis. 4: 19, 20) namun ketaatan terhadap peraturan penguasa tetap diindahkan, selama kewajiban yang dilakukan untuk membangun hal-hal yang berguna (Kent, 2008).

Sikap tunduk kepada pemerintah juga dituliskan Roma 13:1-7. Rasul Paulus dalam konteks tersebut menjadikan ketundukan terhadap pemerintah dalam bagian hal praktis kehidupan umat Kristen di Roma. Jemaat kota Roma yang terdiri dari orang Yahudi dan non-Yahudi memiliki posisi yang sama, yaitu ada di bawah kekuasaan pemerintah Romawi. Pada kokteks saat itu Rasul Paulus berhadapan dengan orang-orang Yahudi yang memiliki konsep kemerdekaan dengan jalan melakukan pemberontakan dan perlawanan terhadap penguasa Romawi. Rasul Paulus menulis surat Roma pasal 13:1-7 memberikan nasihat agar orang Kristen tidak mengikuti sikap para pemberontak Yudaisme (Ayawaila, 2017). Dalam tulisannya Borg (1973) menjelaskan bahwa tindakan Pemberontak Yudaisme telah sampai ke Galilea. Salah satunya adalah golongan Zelot yang memiliki keyakinan tidak ada raja untuk bangsa Yahudi kecuali Allah YHWH, dan tidak ada kewajiban membayar pajak kepada Kaisar, kecuali hanya kepada Allah. Kelompok pemberontak Yudaisme melakukan tindakan pemberontakan secara aktif dengan keyakinan bahwa Allah YHWH tidak akan menolong, jika mereka tidak melakukan tindakan kekerasan untuk membebaskan diri. Kelompok pemberontak memiliki tujuan untuk menentang dan meniadakan pemerintahan sipil. Sehingga kelompok tersebut tidak hanya melakukan teror terhadap kekaisaran Romawi, namun juga menteror sesama bangsa Yahudi yang membayar pajak kepada kaisar Romawi. Paulus tidak setuju karena bertentangan dengan sikap Kristen. Namun bagi sebagian umat Yahudi, sikap itu dibenarkan (Borg, 1973). Rungkat (2010) dalam bukunya Theologia Politik Yesus mengutip John Howard Yoder menjelaskan bahwa pemerintah atau Kaisar Romawi pada saat itu me- rupakan instrumen Allah untuk memberikan keamanan dari kejahatan dan sebagai alat menegakkan keadilan. Dengan demikian Rasul Paulus ingin menunjukkan adanya perbedaan pandangan sikap antara pengikut Kristus dan pemberontak Yudaisme terhadap Kaisar Romawi serta menekankan pandangan bahwa pengikut Kristus dapat menjadi warga negara yang baik.

Perjanjian Baru menunjukkan prinsip bahwa pengikut Kristus wajib menunjukkan sikap mendoakan pemerintah. Wright (2016) menuliskan prinsip 'pelayan imam' tetap diteruskan dalam konteks Perjanjian Baru, yaitu dalam 1Timotius 2: 1-4 yang merupakan perintah Paulus kepada Timotius agar berdoa bagi raja-raja dan semua pembesar, 1Petrus 2:9-17 yang menunjukkan pemahaman Petrus yang menunjukkan umat Israel yang percaya kepada Kristus sebagai 'imamat yang rajani' (Supriadi \& Halawa, 2018) dan Roma 15:16 yang menuliskan pemikiran Paulus bahwa umat Kristen sebagai pemberita Injil bagi bangsa-bangsa bukan Yahudi (Wright, 2016). Calvin (2011) dalam 'Institutio' secara khusus membahas tentang pemerintahan sipil menyarankan prinsip ketaatan terhadap pemerintah dan mendoakan pemerintah yang lalim. Dengan demikian Perjanjian Baru mengajarkan perlunya ketaatan kepada pemerintah selama pemerintah tetap menjadi alat Allah untuk memberikan jaminan keamanan dan keadilan bagi rakyat. Ketaatan terhadap kebijakan dan aturan penguasa yang baik adalah kewajiban para pengikut Kristus.

\section{Wujud Ketaatan Gereja Terhadap Pemerintah Indonesia Pada Masa PandemiCovid-19}

Darmaputera menuliskan sebuah sikap etis terhadap peraturan pemerintah yaitu 'ketidaktaatan yang bertanggungjawab', artinya orang bisa tidak taat kepada pemerintah jika kebijakan pemerintah tidak sesuai dengan bertentangan dengan kebenaran (Boiliu, 2018). Sistem pemerintahan di Indonesia adalah demokrasi konstitusional (demokrasi Pancasila). Pemerintah dalam sistem demokrasi tidak dibe- 
narkan bertindak sewenang-wenang kepada warga karena ada kekuasaan pemerintah dituliskan dalam konstitusi (constitutional) (Crouch, 1982). Protokol kesehatan yang diberlakukan oleh pemerintah adalah hasil keputusan bersama antara Presiden dan menteri, sehingga rumusan protokol kesehatan bukanlah kepentingan politik yang bertujuan menindas rakyat. Rumusan protokol kesehatan bertujuan untuk menekan perkembangan penularan Covid-19. Berdasarkan prinsip ketaatan dalam Perjanjian Lama dan Perjanjian Baru maka setiap orang percaya di Indonesia wajib untuk menerima dan melaksanakan protokol kesehatan dengan baik.

Berita terbaru menunjukkan bahwa Indonesia berhasil menekan angka penyebaran Covid-19 dan mengurangi angka kematian akibat Covid-19, hal tersebut menunjukkan bahwa aturan yang ditetapkan pemerintah adalah sebuah terobosan yang baik dan positif. Pemerintah juga telah memberikan solusi untuk menolong masyarakat yang mengalami dampak pandemi Covid-19, baik masalah ekonomi, pendidikan, kesehatan dan lain-lain. Tindakan pemerintah tersebut menunjukkan bahwa kebijakan yang dilakukan pemerintah menunjukkan sebuah respons kepedulian pemerintah atas dampak pandemic Covid19 (Lukito, 2020). Berdasarkan landasan teologis ketaatan yang telah dikaji, menunjukkan bahwa pemerintah Indonesia masih pada status sebagai instrumen Allah untuk menegakkan kebijakan yang adil dan benar. Dengan demikian secara khusus umat Kristen di Indonesia hendaknya tetap menunjukkan sikap yang taat kepada protokol kesehatan dan mendukung pemerintah dalam menopang sesama yang terdampak oleh pandemi Covid-19, dengan memberikan petrolongan.

Pemerintah telah membuktikan kinerja yang baik selama masa pandemic Covid-19 melakukan penanganan medis dan pemulihan ekonomi. Pemerintah telah memberikan fasilitas pelayanan medis kepada masyarakat yang terdampak Covid-19 dan itu berlaku untuk semua masyarakat Indonesia tanpa ada melakukan diskriminasi karena agama, bahkan pe- merintah berusaha menyediakan vaksin bagi masyarakat Indonesia secara gratis. Pemerintah Indonesia juga melakukan terobosan untuk masalah ekonomi keluarga yang kurang mampu melalui bantuan sosial, baik dalam bentuk uang tunai sebesar Rp 37,4 Triliun bagi 10 Juta Keluarga dan sembako Rp 43,6 Triliun bagi 20 Juta keluarga di Indonesia (Tuwu, 2020). Pemerintah juga memberikan bantuan untuk pelaksanaan pendidikan secara daring dengan menggunakan fasilitas televisi negara yaitu Televisi Republik Indonesia (TVRI) dan memberikan kuota data internet, baik kepada guru dan siswa/mahasiswa (Asmuni, 2020). Pemerintah juga tidak menutup diri dari saran dan kritik segenap lapisan masyarakat. Tindakan pemerintah Indonesia merupakan tindakan yang benar dan baik. Pemerintah mencoba mengatasi masalah pandemi Covid-19 dalam berbagai aspek kehidupan manusia. Berdasarkan landasan teologis ketaatan terhadap pemerintah maka pemerintah Indonesia masih memberikan jaminan kesejahteraan kepada rakyat Indonesia, secara khusus kepada umat Kristen. Dengan demikian masyarakat Indonesia, secara khusus umat Kristen hendaknya menunjukkan sikap hormat kepada Pemerintah dan mewujudkan ketaatan dalam menerapkan protokol kesehatan.

\section{KESIMPULAN}

Kesimpulan penelitian ini menunjukkan pemerintah Indonesia selama wabah pandemi Covid-19 masih tetap menunjukkan kebijakan yang menolong seluruh warga Indonesia. Berdasarkan analisis kasus berkembangnya penyebaran Covid-19 karena kurangnya ketaatan masyarakat dalam melakukan protokol kesehatan, maka umat Kristen di Indonesia wajib menjadi pelopor dalam menerapkan protokol kesehatan. Kajian teologis tentang ketaatan terhadap pemerintah adalah dasar penting yang wajib dipahami oleh seluruh umat Kristen dan para pemimpin gereja, agar memiliki kesadaran yang tinggi untuk menunjukkan ketaatan terhadap kebijakan pemerintah. Umat Kristen di Indonesia hendaknya melihat fakta bahwa apa yang dikerjakan oleh Pemerintah pada 
masa pandemi Covid-19 tetap memperhatikan nilainilai keadilan dan kemanusiaan, meskipun tidak bisa secara ideal semua dapat merasakan, namun upaya baik yang telah pemerintah lakukan wajib didukung. Berdasarkan situasi keamanan saat ini maka pemerintah Indonesia masih pada kondisi sebagai instrumen atau alat Allah untuk melindungi umat Kristen di Indonesia. Dengan demikian umat Kristen di Indonesia pada masa pandemi Covid-19 ini tetap wajib mengikuti protokol kesehatan, mendukung melalui doa segala upaya pemerintah dalam menangani penyebaran Covid-19 dan turut berperan aktif dalam mensosialisasikan kebijakan pemerintah kepada sesama warga Indonesia agar penanganan pandemi Covid-19 semakin efektif hingga vaksin ditemukan dan dibagikan kepada seluruh masyarakat. Penulis menyarankan agar seluruh warga gereja atau umat Kristen bisa menunjukkan sikap hormat kepada Pemerintah Indonesia saat ini, menghargai kebijakan yang dibuat pemerintah dengan baik, menilai positif kebijakan pemerintah yang sedang berupaya mengatasi pandemi Covid-19 dan pemulihan perekonomian negara. Sehingga para pemimpin gereja bisa mengatur substansi isi dalam pengajaran selama pandemi Covid-19 agar tetap memberikan pertumbuhan iman yang sehat bagi jemaat dan para pemimpin gereja harus bisa menetapkan skala prioritas membedakan antara biaya kehidupan keluarga dan operasional gereja. Karena pemerintah tetap berusaha menjaga kebutuhan ekonomi keluarga Indonesia agar tercukupi dengan program bantuan sosial yang telah dilakukan.

Kontribusi penelitian tentang landasan teologi ketaatan adalah sebagai upaya bahan edukasi secara khusus kepada umat Kristen di Indonesia tentang sikap ketaatan terhadap peraturan pemerintah. Pertama, umat Kristen di Indonesia dapat menjadi pelopor ketaatan dalam protokol kesehatan, meskipun tetap ada korban Covid-19 dari umat Kristen. Kedua, umat Kristen di Indonesia diharapkan dapat menunjukkan ketaatan terhadap kebijakan pemerintah pada masa pandemi Covid-19, baik itu kebijakan tentang vaksin, bantuan sosial dan pendidikan. Kebijakan yang baik dari pemerintah perlu disadari oleh umat Kristen masih memiliki kekurangan, namun hendaknya umat Kristen di Indonesia tetap bersabar menyikapi kekurangan dalam realisasi kebijakan. Sehingga tidak perlu umat Krsiten di Indonesia melakukan aksi-aksi anarkis atau melakukan penistaan simbol negara. Ketiga, umat Kristen di Indonesia menunjukkan ketaatan secara spiritualitas yaitu berdoa bagi bangsa dan negara serta pemerintah yang sedang berjuang membangun berbagai aspek kehidupan bangsa di tengah suasan pandemi Covid-19. Jika memang umat Kristen kecewa terhadap salah satu kebijakan pemerintah yang dinilai melanggar hukum, maka umat Kristen tetap memiliki hak untuk menggunakan jalur resmi pemerintah yaitu jalur hukum untuk membela haknya.

Penelitian ini merupakan riset awal penulis terhadap realitas kehidupan bangsa Indonesia secara khusus landasan teologis ketaatan umat Kristen di Indonesia dalam masa pandemi Covid-19. Penelitian ini hanya baru menyelesaikan sebuah masalah, yaitu prinsip ketaatan terhadap protokol kesehatan dan kebijakan pemerintah di masa pandemi Covid-19. Beberapa point penting yang penulis pikirkan untuk dikembangkan, pertama, apakah manusia benarbenar memiliki natur taat kepada pemerintah? Karena kaitan dosa dan ketaatan perlu diteliti lebih dalam dan cermat. Hal tersebut sangat penting agar mendapatkan konsep mendalam tetang kepasifan manusia dalam menerapkan protokol kesehatan. Kedua, meneliti hasil pengendalian Covid-19 di negara-negara dengan ideologi komunis yang menekankan ketaatan mutlak kepada pemimpin negara, sehingga akan ada data perbandingan manakah yang lebih efektif dalam implementasinya, ketaatan dalam konsep teologis atau ketaatan dalam konsep komunis. Demikian kesimpulan, saran, kontribusi dan ide pengembangan terhadap tulisan ini. 


\section{DAFTAR RUJUKAN}

Arifianto, Y. A., \& Santo, J. C. (2020). Tinjauan Trilogi Kerukunan Umat Beragama Berdasarkan Perspektif Iman Kristen. Angelion: Jurnal Teologi Dan Pendidikan Kristen, 1(1), 1-14.

Asmuni, A. (2020). Problematika Pembelajaran Daring di Masa Pandemi Covid-19 dan Solusi Pemecahannya. Jurnal Paedagogy, 7(4), 281. https://doi.org/10.33394/jp.v7i4.2941

Ayawaila, E. M. (2017). Makna Hidup Dalam Kasih Menurut Rasul Paulus Berdasarkan Roma 12:9-21. Manna Rafflesia, 3(2), 157-175. https://doi.org/10.38091/man_raf.v3i2.73

B, S., \& P, M. (2021, January 7). Wawancara Majelis GEKISIA Kota Bengkulu (M. N. Supriadi, Interviewer). (Bengkulu).

Balchin, J., Cotterell, P., Evans, M., Kirby, G., Knight, P., \& Derek, T. (2000). Intisari Perjanjian Lama (R. Rimba, Trans.). Jakarta: Persekutuan Pembaca Alkitab.

Bengkulu, D. (2021, August 1). Info Perkembangan Kasus COVID-19 di Kab. Bengkulu Selatan [Covid19.bengkuluselatankab.go.id].

Retrieved 1 August 2021, from Covid-19 Kab. Bengkulu Selatan website: https://covid19.bengkuluselatankab.go.id/

Berutu, I., \& Siahaan, H. E. R. (2020). Menerapkan Kelompok Sel Virtual Di Masa Pandemi Covid-19. SOTIRIA (Jurnal Theologia Dan Pendidikan Agama Kristen), 3(1), 53-65.

Boiliu, N. I. (2018). Etika Teologi Politik: Analisis Etis Teologis Ketaatan kepada Pemerintah. Revitalisasi Indonesia Melalui Identitas Kemajemukan Berdasarkan Pancasila, 199209. Jakarta: UKI Press. Retrieved from http://repository.uki.ac.id/840/1/Ibrahim.pdf Borg, M. (1973). A New Context for Romans xiii. New Testament Studies, 19(2), 205-218. https://doi.org/10.1017/S002868850000394 5
Calvin, Y. (2011). Institutio: Pengajaran Agama Kristen (Ny. Winarsih, J. S. Aritonang, Arifin, \& Th. V. den End, Trans.). Jakarta: BPK Gunung Mulia.

Crouch, H. (1982). Perkembangan Politik dan Modernisasi. Jakarta: Citra Swatama.

Devlieghere, J., \& Roose, R. (2020). Social work during the Covid-19 pandemic: Staying close while maintaining social distancing. European Journal of Social Work, 23(4), 541-542.

https://doi.org/10.1080/13691457.2020.1794 288

Dwiraharjo, S. (2020). Konstruksi Teologis Gereja Digital: Sebuah Refleksi Biblis Ibadah Online Di Masa Pandemi Covid-19. EPIGRAPHE: Jurnal Teologi Dan Pelayanan Kristiani, 4(1), 1-17.

Hutahaean, H., Silalahi, B. S., \& Simanjuntak, L. Z. (2020). Spiritualitas Pandemik: Tinjauan Fenomenologi Ibadah Di Rumah. Evangelikal: Jurnal Teologi Injili Dan Pembinaan Warga Jemaat, 4(2), 235-250.

John. (2020a, December 30). Wawancara Jemaat GPdI Sion (M. N. Supriadi, Interviewer). (Kota Bengkulu).

Kent, H. A. (2008). Matius. In E. F. Harrison \& Charles F. Pfeiffer (Eds.), The Wycliffe Bible Commentary (Vol. 3, p. 35). Malang: Gandum Mas.

Lukito, D. L. (2020). Iman Kristen di Tengah Pandemi: Hidup Realistis Ketika Penderitaan dan Kematian Merebak.

Marbun, P. (2020). Optimalisasi Fungsi Rumah Sebagai Tempat Pembinaan Warga Gereja di Masa Pandemi Covid-19. DIEGESIS: Jurnal Teologi Kharismatika, 3(1), 26-43.

Mawikere, M. C. S. (2019). Sola Experientia: Suatu Analisis Terhadap Teologi Schleiermacher. Evangelikal: Jurnal Teologi Injili Dan Pembinaan Warga Jemaat, 3(2), 225-241. 
N, N. (2020a, November 21). Situasi Virus Covid-19

Di Indonesia [Https://covid19.go.id/].

Retrieved 21 November 2020, from Komite

Penanganan Covid-19 Dan Pemulihan

Ekonomi Nasional website:

https://covid19.who.int/

N, N. (2020b, November 21). WHO Coronavirus

Disease (COVID-19) Dashboard

[Https://covid19.who.int/]. Retrieved 21

November 2020, from World Health

Organization website:

https://covid19.who.int/

Nego, O. (2020). Teologi Multikultural sebagai

Respon terhadap Meningkatnya Eskalasi

Politik Identitas di Indonesia. PASCA: Jurnal

Teologi Dan Pendidikan Agama Kristen, 16(2),

121-139.

https://doi.org/10.46494/psc.v16i2.109

Novalina, M. (2020). Misi Umat Allah (Book

Review). PASCA: Jurnal Teologi Dan

Pendidikan Agama Kristen, 16(2), 183-187. https://doi.org/10.46494/psc.v16i2.111

PEN, VNP, \& YOY. (2020b, Oktober). Realisasi Bantuan Sosial Tunai Capai 82\%, untuk jaga daya beli masyarakat [Https://covid19.who.int/]. Retrieved 21 November 2020, from Komite Penanganan Covid-19 Dan Pemulihan Ekonomi Nasional website:

https://covid19.go.id/berita/realisasi-

bantuan-sosial-tunai-capai-82-untuk-jaga-

daya-beli-masyarakat

Pentury, T. (2020, April 20). Surat Himbauan Dirjen [Bimaskristen.kemenag.go.id]. Retrieved 21 November 2020, from Kementrian Agama RI Ditjen Bimas Kristen website: https://bimaskristen.kemenag.go.id/infopenti ng-51-himbauan-dirjen-bimas-kristenterkait-wabah-covid19-untuk-seluruhgerejagereja-di-indonesia.html

Putri, W. S. (2020, April 1). Pakar Matematika UI Menghitung Penderita Virus Corona Akan Mencapai Ribuan Kasus dan Berakhir Awal
September Jika... [Gridframe.id]. Retrieved from Grid Frame website: https://fame.grid.id/amp/462085904/pakarmatematika-ui-menghitung-penderita-viruscorona-akan-mencapai-ribuan-kasus-danberakhir-awal-september-jika?page=all

Ridha, N. (2017). Proses Penelitian, Masalah, Variabel Dan Paradigma Penelitian. Jurnal Hikmah, 14(1), 9. Retrieved from http://jurnalhikmah.staisumateramedan.ac.id/index.php/hikmah/article/view/ 18

Rungkat, J. (2010). Theologia Politik Yesus. Batu: Departemen Multi-Media YPPII.

Silitonga, R. (2020). Respon Gereja Atas Pandemik Corona Virus Desease 2019 Dan Ibadah Di Rumah. Manna Rafflesia, 6(2), 86-111. https://doi.org/10.38091/man_raf.v6i2.125

Sugianto, M. F. (2020). Doktrin Kesembuhan Dalam Pelayanan Pentakosta Di Era Pandemi Covid-19. Jurnal Teologi Amreta (ISSN: 2599-3100), 4(1).

Supriadi, M. N., \& Halawa, I. K. (2018). Makna Penderitaan Kristus Dalam 1Petrus 2: 18-21. Manna Rafflesia, 5(1), 69-91. https://doi.org/10.38091/man_raf.v5i1.99

Supriadi, M. N., \& Halawa, I. K. (2020). Kajian Teologis Makna Inkarnasi Kristus Dan Implementasinya Bagi Spiritualitas Kristen Pada Konteks Pandemik Corona Viruses Disease 2019. Sesawi: Jurnal Teologi Dan Pendidikan, 2(1), 126-142. Retrieved from http://sttsabdaagung.ac.id/ejournal/index.php/sesawi/article/view/16

Supriadi, M. N., Halawa, I. K., \& Daeli, R. (2020). Tinjauan Teologis Realisasi Perintah Jangan Mencuri Dalam Keluaran 20: 15 Berdasarkan Perspektif Sejarah Penebusan. JURNAL LUXNOS, 6(2), 213-234.

Susanta, Y. K. (2019). Orang Kristen Dan Politik: Belajar Dari Kasus Salomo Dan Adonia Dalam Persaingan Menuju Takhta. 
DUNAMIS: Jurnal Teologi Dan Pendidikan Kristiani, 4(1), 22-36.

Thorik, S. H. (2020). Efektivitas Pembatasan Sosial Berskala Besar di Indonesia Dalam Penanggulangan Pandemi Covid-19. 'ADALAH, 4(1), 115-120. https://doi.org/10.15408/adalah.v4i1.15506

Tuwu, D. (2020). Kebijakan Pemerintah Dalam Penanganan Pandemi Covid-19. Journal Publicuho, 3(2), 267. https://doi.org/10.35817/jpu.v3i2.12535

Usmin. (2020c, September 6). 5 Kabupaten di Bengkulu Berstatus Zona Hijau Covid-19 [Www.beritasatu.com]. Retrieved 1 August 2021, from Berita Satu website: https://www.beritasatu.com/nasional/653647 15-kabupaten-di-bengkulu-berstatus-zonahijau-covid19

Wright, C. J. H. (2016). Hidup Sebagai Umat Allah: Etika Perjanjian Lama (L. S. Kie, Trans.). Jakarta: BPK Gunung Mulia.

Zaluchu, S. E. (2020a). Pendekatan Reader Response Criticism terhadap Narasi Tulah di Mesir dalam Peristiwa Keluaran. Religious: Jurnal Studi Agama-Agama Dan Lintas Budaya, 4(4), 267-276.

Zaluchu, S. E. (2020b). Strategi Penelitian Kualitatif Dan Kuantitatif Di Dalam Penelitian Agama. Evangelikal: Jurnal Teologi Injili Dan Pembinaan Warga Jemaat, 4(1), 28-38. https://dx.doi.org/10.46445/ejti.v4i1.167 